Synthesis, vol. $24 \mathrm{n}^{\circ}$ 2, e025, diciembre 2017. ISSN 1851-779X

Universidad Nacional de La Plata.

Facultad de Humanidades y Ciencias de la Educación.

Synthesis

Centro de Estudios Helénicos

\title{
Viviana Gastaldi, Claudia Fernández, Guillermo De Santis (Eds.) Imaginarios de la integración y la marginalidad en el drama ático. Editorial de la Universidad Nacional del Sur, Bahía Blanca, 2016, 247 pp.
}

\author{
María Luz Mattioli * \\ * Universidad Nacional de La Plata, Argentina
}

Cita sugerida: Mattioli, M. L.(2017). [Revisión del libro Imaginarios de la integración y la marginalidad en el drama ático, por Viviana Gastaldi, Claudia Fernández, Guillermo De Santis]. Synthesis, 24 (2), e025. https://doi.org/10.24215/1851779Xe025 


\section{Viviana Gastaldi, Claudia Fernández, Guillermo De Santis (Eds.) Imaginarios de la integración y la marginalidad en el drama ático. Editorial de la Universidad Nacional del Sur, Bahía Blanca, 2016, 247 pp.}

Maria Luz Mattioli

Universidad Nacional de La Plata, Argentina

El volumen Imaginarios de la integración y la marginalidad en el drama ático editado en el año 2016 bajo la coordinación de Viviana Gastaldi, Claudia N. Fernández y Guillermo de Santis aborda en cada uno de los capítulos los alcances de la noción de "imaginario", especialmente el concepto de "imaginario socio-jurídico" en función de la antítesis integración/marginalidad y desde allí los autores plantean cómo aparecen estas particularidades en los contextos referenciales del drama ático. El libro contiene una pequeña introducción que pone de relieve los límites desde los cuales se aborda el concepto de "imaginario social", entendido fundamentalmente desde un punto de vista sociológico.

Los autores realizan un recorrido por Avispas de Aristófanes (Buis, E.), Orestía de Esquilo (De Santis, G.), Lisistrata de Aristófanes (Fernández, C.), la centralidad de la enfermedad y el modo en que se reafirma la marginalidad del héroe (Gambón, L.), la atimía como castigo en Orestía de Esquilo y en Heracles, Orestes, Heraclidas e Ifigenia en Táuride de Eurípides (Gastaldi, V.) y la figura de Medea y Dioniso como agentes de destrucción de la pólis (Rodríguez Cidre, E. ) ofreciendo de ese modo distintas perspectivas desde las cuales el lector puede pensar el concepto de imaginario social, de sociedad, de orden social, el modo en que las relaciones e instituciones se presentan como objetos de una actividad ficcional, no real, inserta en un fenómeno colectivo y a partir de la que se fijan modelos formadores.

En el primer capítulo, "Imaginarios del espacio judicial y cartografía del derecho en Avispas de Aristófanes: apuntes para una nomotopía cómica" (pp. 13-60) Emiliano J. Buis analiza la poética del espacio en clave de imaginería a través de dos aspectos: por un lado, el derecho como práctica habitual ateniense y, por otro, el espacio como vertebrador físico y material de toda experiencia social. El capítulo se compone de distintos apartados en los que el autor estudia la construcción ficcional de un imaginario espacial del derecho: "imaginario(s) del tópos", "Espacios litigiosos o cartografías jurisdiccionales", "la 'nomotopía' como imaginario en Avispas" e "imaginando el espacio, construyendo la nomotopía: a modo de conclusión”. Cada uno de los aspectos analizados le permiten al autor demostrar cómo "la comedia antigua se alza como un territorio de contienda en el que se propone reflexionar sobre los peligros del nómos injusto o distorsionado por intereses espurios" (p. 37). E. Buis ofrece un análisis por demás interesante para pensar cómo a través de los espacios escénicos que son identificados por los espectadores, Aristófanes logra generar en el público reflexiones vinculadas con la praxis judicial y la semiótica del nómos, de ese modo el autor demuestra cómo el comediógrafo pone en escena un "imaginario" compartido con el público presente.

En el siguiente capítulo, "Exclusión/inclusión de las Erinias: banquete, espacio político y medicina en Orestía de Esquilo" (pp. 61-98), Guillermo de Santis se alinea bajo las palabras de Gagné para indagar en cómo la resolución de la trilogía esquilea coloca a las Erinias en el centro de la ciudad y cómo su participación en el banquete resulta un tema constante en Orestía. El autor analiza el banquete ritual y comunitario como una de las manifestaciones esenciales de la xenía. El capítulo se compone de dos apartados en los que estudia "El banquete en Agamenón", "El festín de las Erinias: espacio político y enfermedad" y una "conclusión”. En 
el primero parte de analizar los vv. 729-736 para mostrar cómo Esquilo se vale de imágenes que le permiten explicar el momento de una sociedad y de ese modo se desarrolla tanto la idea de xenía como así también la de "imaginarios sociales" entendidos como "esquemas socialmente construidos que nos permiten percibir, explicar e intervenir en lo que en cada sistema social se tenga por realidad” (p. 64). G. De Santis analiza cómo en Orestía los imaginarios producen una imagen de peligro e inestabilidad que se opone a la expectativa de estabilidad de los espectadores. En el segundo apartado, el autor parte de los vv. 243-247 para observar cómo el Coro ofrece una imagen del banquete en su "deber ser", como expresión ritual del orden y estabilidad de la comunidad, de la fertilidad y de la continuidad del $o \hat{\imath} k o s$. A esta imagen se contrapone el momento en que Apolo expulsa a las Erinias de su templo (vv. 185-195). Así, G. De Santis ejemplifica de manera muy singular los espacios de inclusión y exclusión y explica cómo la exclusión de las Erinias se plantea en términos políticos que hacen referencia y se cruzan semánticamente con la medicina y la biología. El autor concluye en cómo la valencia médica del "aniquilamiento del esperma" se entrecruza con el imaginario del "espacio excluido" para demostrar que "las celebraciones de las Erinias no dan cuenta de la vitalidad de una sociedad, sino, por el contrario, de su peligro de disolución" (p. 84). En este capítulo, G. De Santis propone una lectura integral desde distintos puntos de vista que se entrecruzan y permiten advertir cómo se configura a través de diversas imágenes un "imaginario de exclusión de las Erinias".

"Lisístrata, la estratega" (pp. 99-129) es el tercer capítulo del volumen. Su autora, Claudia N. Fernández, se detiene en el estudio del protagonismo de Lisístrata y en cómo el intento de las mujeres por llevar adelante las cuestiones públicas y decidir sobre el destino de la pólis "resulta una provocativa inversión de la situación de la Atenas de la época” (p. 100). Sin embargo, para C. Fernández, Lisístrata se destaca de las otras figuras femeninas que protagonizan esta comedia por ser un personaje superior y excepcional. Entre todos sus atributos masculinos se destaca la competencia de Lisístrata para hablar sobre cuestiones de guerra. El objetivo de la autora es destacar y analizar los tecnicismos propios del lenguaje bélico-militar y ahondar sobre las ambigüedades, contradicciones y tensiones no resueltas. La propuesta de Fernández resulta atractiva puesto que parte de mostrar cómo la "pose de guerrera” de Lisístrata es adoptada por quien defiende la perspectiva anti-bélica. Así, se registra una "ostensible oposición entre lo que el personaje dice y hace y la forma en cómo lo dice y cómo lo hace" (p. 102).

A lo largo de su análisis, C. Fernández se detiene en dos pasajes que contienen una serie de términos propios del registro de la lengua militar que no han sido mayormente visibilizados en las traducciones modernas de la comedia. El primero de los pasajes abarca los vv. 175-179 y el segundo los vv. 453-461. El análisis y la minuciosa explicación filológica de cada uno de los fragmentos le permiten a la autora mostrar la doble naturaleza de Lisístrata que, aunque mujer, habla como hombre; aunque pacífica, hace la guerra. Si bien Lisistrata es la comedia de Aristófanes que más se ha leído y representado, en el presente capítulo C. Fernández propone una lectura y un análisis que entiende a la comedia como una denuncia contra la incompetencia de los varones que no han sabido conducir la ciudad. Si el final de la comedia analizada se plantea en términos plenamente masculinos, la autora concluye que del mismo modo debe ser comprendido el costado militar de Lisístrata: "para triunfar, debe asumir el rol de la principal función que podía ejercer un varón adulto libre, la del militar estratega, la máxima autoridad militar y política del imaginario social ateniense" (p. 116).

En "Enfermedad y marginalidad en el drama: construyendo la gramática de la locura" (pp. 131-165), Lidia Gambón analiza cómo la tragedia está atravesada tanto por una "visión patológica” como así también por la marginalidad que impone al personaje su "medida heroica". El capítulo posee distintos apartados como "Enfermedad y marginalidad en el drama: tragedia y medicina en diálogo", "Definiendo la perspectiva: algunos otros aspectos del imaginario nosológico" y "Enfermedad, marginalidad y locura" que posee dos partes: “a) Un término que habla en imágenes: tarásso" y "b) Una tragedia que habla en imágenes: Heracles y la gramática trágica de la locura”. En el recorrido que traza, L. Gambón demuestra cómo la tragedia plasma la perspectiva patológica tanto "en la imagen del héroe trágico sufriente, a quien suele presentar como víctima 
de terribles nósoi (las locuras de Orestes, Áyax o Heracles, la herida de Filoctetes), como también en su propia construcción simbólica, que define la normalidad a través de la nosología y hace de la crisis el punto de la metabolé trágica" (pp. 131-132). De ese modo, la imagen de la nósos se convierte en una imagen que se comprende y aprehende en profundidad como metáfora conceptual. Dentro de esta metáfora flexible, denominada "estructural", la autora delimita la perspectiva de la marginalidad heroica, especialmente aquella que hace referencia a la locura.

El análisis propuesto le permite a la autora demostrar e ilustrar cómo en las tragedias que se conservan se recurre con frecuencia al tratamiento de la metáfora "estructural" ya sea para describir el sufrimiento del héroe o bien para exhibir la disfunción de las instituciones que componen el tejido social. El relevamiento filológico que realiza L. Gambón en el presente capítulo le permite evidenciar la importancia del verbo tárasso "como término que define la manía en la tragedia ática, y su particular contribución al imaginario nosológico en Heracles" (p. 150). El análisis propuesto es realmente interesante puesto que le permite al lector transitar por un campo semántico diverso y observar cómo en el verbo tárasso confluyen tanto la imagen del concepto de crisis individual (locura) como así también de la crisis social (stásis). De esa manera -concluye la autorase consolida "la metáfora del cuerpo político en el así denominado moment tragique" (p.150).

El capítulo a cargo de Viviana E. Gastaldi, "La atimía como forma de exclusión en la antigua Grecia. Realidad jurídica y representación trágica” (pp. 167-198), se compone de distintos apartados en los que la autora analiza la evolución semántica del concepto de atimía en función de distintos aspectos. Así, el capítulo se estructura en "Acerca del ser ciudadano", "Atimía en la realidad jurídica de Atenas", "Atimía en la escena trágica" que se subdivide en "Atimía por posible deserción a la venganza de sangre (automática), "Atimía automática y míasma por homicidio" y "Atimía con sentencia (por homicidio)" ofreciendo de ese modo un análisis minucioso del concepto a partir de fragmentos de la tragedia que testimonian las distintas maneras de representación de la atimía en Atenas. A lo largo del análisis, la autora explica cómo el castigo de atimía estaba ya presente en la época homérica y cómo el uso del término refiere esencialmente a la privación del honor. El término implica en un primer momento humillación y no aún degradación jurídica tal cual lo ejemplifica la autora con los versos 647-648 del Canto I de Ilíada. V. Gastaldi transita la evolución del término y explica cómo "en la polis clásica átimos adquiere, por oposición a epitimos, el sentido jurídico de degradación y la atimía deviene una pena impuesta por ley: en el derecho ático implica la privación del ejercicio de todos o parte de sus derechos ligados a la condición de ciudadanía” (p. 170). A partir de estas consideraciones, la autora propone revisar el concepto a la luz de la escena trágica. Para eso retoma las palabras de Hall cuando afirma que la dimensión cívica de la tragedia se revela en su repetida exploración del tema del exilio y la pérdida de derechos de un ciudadano. De este modo -indica V. Gastaldi- el género trágico se constituye en una fuente válida para el estudio del derecho ateniense y de modo más general, de los valores de la cultura jurídica griega. A modo de conclusión, y luego de un exhaustivo análisis, la autora sostiene que "el tópico inclusión/ exclusión formaba parte de la construcción identitaria ateniense, y en este marco, el 'otro' marcado por el delito encontraba en el teatro una forma válida y particular de expresión” (p. 188).

En el último capítulo, "El imaginario del péplos trágico: Medea y Dioniso como agentes de destrucción de la pólis”, Elsa Rodríguez Cidre analiza el imaginario de los péploi trágicos de Medea y Dioniso para comparar la forma en que ambos victimarios destruyen mediante diversas tékhnai a los reyes de Corinto y de Tebas y, por extensión, a las ciudades mismas. Una de las ideas principales que la autora analizará a lo largo del capítulo es que en el imaginario de la pólis clásica el vestido conforma un elemento estructurante y "opera dando cuenta de una diferencia fundamental, la que distingue al mundo humano y ordenado de la pólis del mundo salvaje animal" (p. 201). A través de un minucioso análisis filológico, E. Rodríguez Cidre demuestra cómo en ambas obras la vestimenta está presentada como una artimaña. La autora propone dos apartados, en el primero de ellos, "Matar con un peplo" analiza cómo en Medea "la relación entre peplo y destrucción no puede ser más directa desde el momento en que los dones de la bárbara conforman por sí mismos el arma que produce la muerte y es por ello que se brinda mayor insistencia y detalle en torno de lo tanático" (p. 204). En 
primer lugar, E. Rodríguez Cidre se detiene y analiza a partir de fragmentos seleccionados la teratologización de los dones nupciales. En un segundo momento, piensa qué relaciones inter e intratextuales propone Medea con otras tragedias como Prometeo Encadenado de Esquilo y Traquinias de Sófocles. En el segundo apartado, "Morir con el peplo" propone que "en Bacantes la relación péplos/destrucción es indirecta puesto que estos conforman la trampa que llevará a la muerte al rey pero no son por sí mismos el instrumento fatal” (p. 217). Así, a lo largo de su análisis demuestra cómo el travestimiento de Dioniso supone un juego de valencias divinas, humanas y también bestiales. A modo de conclusión, la autora resalta la idea de que "los péploi se presentan como armas letales en ambas tramas pero lo que importa remarcar es que actúan sobre todo borrando o confundiendo las diferencias que deberían en cambio cimentar" (p. 228).

El volumen Imaginarios de la integración y la marginalidad en el drama ático demuestra cómo el concepto de 'imaginario social' permite entender la realidad en su carácter dinámico y así lo demuestran la pluralidad de aspectos y temáticas específicas que se analizan minuciosamente en cada uno de los capítulos.

El volumen ofrece al lector la posibilidad de reflexionar de manera integral cómo a través del concepto de “imaginario" la sociedad griega fijó y representó simbólicamente sus normas y cómo definió las relaciones vinculares. 